\title{
Evaluation on the Disposal of Radioactive Wastes into the North Pacific
}

\author{
by \\ Yoshio Sugiura, Katsuko Saruhashi \\ Meteorological Research Institute, Tokyo \\ and \\ Yasuo Miyake \\ Geochemistry Research Association, Tokyo \\ (Received May 31, 1976)
}

\begin{abstract}
Evaluation on deep sea disposal of radioactive waste into the North Pacific on the basis of diffusion process is done using a simplified model. The results of calculation by employing different sets of diffusion coefficients on the horizontal and vertical directions show that for the smaller diffusion coefficients discrepancies between relative concentration of nuclides and the law of radioactive disintegration are greater. For larger coefficients, concentration above the site of release approaches mean, homogeneous concentration which satisfies the rule of radioactivity.

From oceanographic and radiological view points, it is concluded that $10^{2} \mathrm{~cm}^{2} / \mathrm{s}$ and $10^{8} \mathrm{~cm}^{2} / \mathrm{s}$ respectively of diffusion coefficient of the vertical and horizontal directions are appropriate and reasonable in the North Pacific for the purpose of dose evaluation.

A New definition of the high-level radioactive waste and other matter is given as follows :

(a) $10 \mathrm{Ci} / \mathrm{t}$ for $\beta / \gamma$ emitter (except tritium), $1 \mathrm{Ci} / \mathrm{t}$ for ${ }^{90} \mathrm{Sr}$ plus ${ }^{137} \mathrm{Cs}$,

(b) $10^{4} \mathrm{Ci} / \mathrm{t}$ for tritium,

(c) No long-lived $\alpha$ emitter may be dumped.
\end{abstract}

\section{Introduction}

There have been a number of studies concerning the evaluation of radiation dose which may be caused by dumping radioactive waste at the bottom of the ocean. Recently, WEBB and MORLEY (1973) published a report on the evaluation of deep ocean disposal of radioactive wastes in the eastern North Atlantic taking the diffusion processes into account. The report by WEBB and MORLEY is very important among others, because the results of their study were reassessed by the Organization for Economic Co-operation and Development (OECD, 1973), and the definition of the high level radioactive waste and other matter unsuitable for dumping at sea was given by the International Atomic Energy Agency (IAEA, 1974) on the basis of their study.

However, there are many questionable points in the WEBB-MORLEY report in regard to appropriateness in the selection of values of turbulent diffusion coefficients, the boundary condition employed and other problems concerning the safety for dumping radioactive wastes at sea. Some of the questions are pointed out in the paper in this number by two of the present authors (MIYASE and SARUHASHI, 1976b). 
The calculation of concentration of radionuclide in sea water by WEBB and MORLEY was done under the assumption that the diffusion coefficients on the vertical and the horizontal directions are respectively $24 \mathrm{~cm}^{2} / \mathrm{s}$ and $10^{4} \mathrm{~cm}^{2} / \mathrm{s}$ in the North Atlantic. According to their calculation the sea area concerned is regarded to be an open system. However, it is evident that the ocean is by no means an open system and also the results of calculations may vary greatly with the different values adopted of the turbulent diffusion coefficients. The question is, "what are the proper values of the diffusion coefficients in the ocean?" Unless reasonable values of the diffusion coefficients are used in the calculation, useful results for the evaluation of deep ocean disposal of radioactive waste can not be obtained.

In this paper, the results of study on the relation between the concentration of radionuclide and the diffusion coefficients, using a simplified model of the North Pacific are reported. From the oceanographic point of view and also taking the law of radioactive disintegration into account, it is concluded that appropriate values of the turbulent diffusion coefficients on the vertical and the horizontal directions are respectively $10^{2} \mathrm{~cm}^{2} / \mathrm{s}$ and $10^{7}$ to $10^{8} \mathrm{~cm}^{2} / \mathrm{s}$ in the North Pacific.

\section{The equations and assumptions used}

1) In the ocean, the large-scale mixing of water takes place through advection, diffusion, convection etc., both on the horizontal and vertical directions. When only the effect due to diffusion processes is taken into account, the following equation is usually used to calculate the concentration of a certain material at a certain point $(x, y, z)$ and at time $t$ when an instantaneous release is done of quantity $Q$ ( $g$ or mole etc.) at time $t=0$, at a point $(x=y=z=0)$ in a stillstanding infinite and homogeneous medium:

$$
\begin{aligned}
C_{i}= & \frac{Q}{(4 \pi t)^{3 / 2}\left(K_{x} K_{y} K_{z}\right)^{1 / 2}} \\
& \exp \left[-\frac{1}{4 t}\left(\frac{X^{2}}{K_{x}}+\frac{Y^{2}}{K_{y}}+\frac{Z^{2}}{K_{z}}\right)\right]
\end{aligned}
$$

where $C_{i}$ is the concentration of a material in an infinite medium and $K_{x}, K_{y}$ and $K_{z}$ are the turbulent diffusion coefficients in the $x$-, $y$ - and $z$-directions. In the case of instantaneous release of $1 \mathrm{Ci}$ of radionuclide at the ocean bottom, the following equation is used in place of Eq. (1):

$$
\begin{aligned}
& C=\frac{1}{4(\pi t)^{3 / 2}\left(K_{x} K_{y} K_{z}\right)^{1 / 2}} \\
& \exp \left[-\frac{1}{4 t}\left(\frac{X^{2}}{K_{x}}+\frac{Y^{2}}{K_{y}}+\frac{Z^{2}}{K_{z}}\right)\right] \exp (-\lambda t) \\
& =A t^{-3 / 2} \exp \left(-B t^{-1}\right) \exp (-\lambda t)
\end{aligned}
$$

where $\lambda$ is a radioactive decay constant. The right-hand side of Eq. (2) consists of three terms, i.e., the first one expressing the concentration at the cloud center which decreases according to the law of the negative $3 / 2$ power with time, the second one expressing the concentration through the cloud which follows a Gaussian distribution and the third one concerning radioactive decay. The product of the first and the second terms $\left(C_{d}\right)$ is common to all radionuclides so far as the same diffusion coefficients are employed.

2) In order to evaluate the effect of radiation due to the deep sea dumping of radioactive waste at the bottom of the North Pacific, a simplified model of the North Pacific is built.

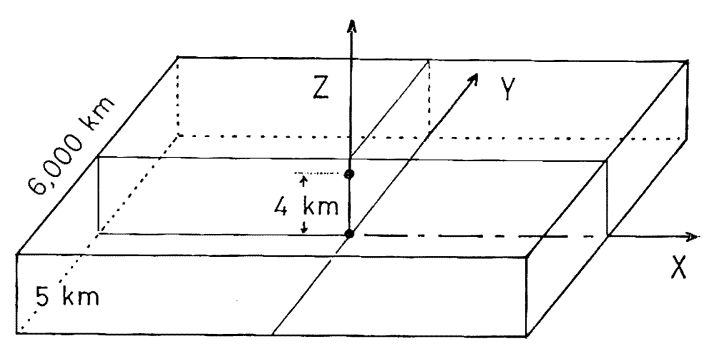

$12,000 \mathrm{~km}$

Fig. 1. Simplified model of the North Pacific Ocean. Point of release is located at the center. 
Fig. 1 shows the model of the North Pacific which has the following dimensions: $5,000 \mathrm{~m}$ deep, $12,000 \mathrm{~km}$ long in the east-west direction and $6,000 \mathrm{~km}$ long in the northsouth. For the sake of simplicity, the center of the bottom is defined as a point of release as well as the origin of a coordinate system.

It is also assumed that the ocean is divided into two layers, i.e., the surface layer with a thickness of $1,000 \mathrm{~m}$ and the deep layer with a thickness of $4,000 \mathrm{~m}$. Another assumption regards the North Pacific as a closed system.

In a closed system, the reflection at the boundary should be taken into account and reflected fractions must be fully summed up as follows:

$$
\begin{aligned}
C_{d}=A t^{-3 / 2} \sum_{x, y, z} \exp \left(-B t^{-1}\right) \\
\sum_{x, y, z} \exp \left(-B t^{-1}\right) \\
=2 \sum_{n_{x}} \exp \left(-\frac{n_{x}{ }^{2} 10^{16}}{4 \bar{K}_{x} t}-\frac{4 \cdot 10^{10}}{K_{z} t}\right) \\
+2 \sum_{n_{y}} \exp \left(-\frac{n_{y}{ }^{2} 10^{16}}{4 K_{y} t}-\frac{4 \cdot 10^{10}}{K_{z} t}\right) \\
+\sum_{n_{z}} \exp \left(-\frac{n_{z}{ }^{2} 10^{10}}{4 K_{z} t}\right)
\end{aligned}
$$

where $n_{x}=6 \times 2 \times i, n_{y}=3 \times 2 \times i, i=1,2,3 \cdots$ $n_{z}=4+2,4+2+8,4+2+8+2, \cdots$.

3) Since most of marine foods are produced in the surface layer of the ocean, for the sake of satety, the highest accumulated concentration in the surface layer at the steady state is estimated in order to keep the radioactivity in marine foods far below a certain dose limit to man. To estimate the surface concentration $\left(C_{a}\right)$, the concentration $\left(C_{c}\right)$ of a radionuclide at the center of the top of the deep layer, or the point 4,000 $\mathrm{m}$ above the site of release, is calculated by using the above equations concerning the diffusive mixing under the given assumptions as described.

In the successive annual release of $1 \mathrm{Ci}$ of a certain nuclide, the accumulated concentration $\left(\Sigma C\right.$ or $\left.C_{c}\right)$ of the nuclide in sea water at the location ( $x=y=0, \quad z=4,000 \mathrm{~m}$ from the bottom) is as follows:

$$
\Sigma C=\sum_{t=1}^{\infty} C_{d} \exp (-\lambda t)
$$

\begin{tabular}{|c|c|c|c|c|c|c|c|}
\hline Nuclide & $\begin{array}{l}\lambda \\
1 / \mathrm{y}\end{array}$ & $\begin{array}{cc}y & 10^{4} \\
z & 1\end{array}$ & $\begin{array}{c}10^{6} \\
1\end{array}$ & $\begin{array}{l}10^{4} \\
10^{2}\end{array}$ & $\begin{array}{l}10^{6} \\
10^{2}\end{array}$ & $\begin{array}{l}10^{8} \\
10^{2}\end{array}$ & $\begin{array}{l}10^{9} \mathrm{~cm}^{2} / \mathrm{s} \\
10^{3} \mathrm{~cm}^{2} / \mathrm{s}\end{array}$ \\
\hline${ }^{60} \mathrm{Co}$ & 0.14 & $9 \times 10^{-30}$ & $9 \times 10^{-32}$ & $1 \times 10^{-19}$ & $1 \times 10^{-21}$ & $1 \times 10^{-23}$ & $2 \times 10^{-23} \mathrm{Ci} / \mathrm{cm}^{3}$ \\
\hline${ }^{3} \mathrm{H}$ & 0.057 & $6 \times 10^{-26}$ & $6 \times 10^{-28}$ & $3 \times 10^{-19}$ & $3 \times 10^{-21}$ & $4 \times 10^{-23}$ & $5 \times 10^{-23}$ \\
\hline${ }^{90} \mathrm{Sr}$ & 0.025 & $2 \times 10^{-23}$ & $2 \times 10^{-25}$ & $5 \times 10^{-19}$ & $5 \times 10^{-21}$ & $1 \times 10^{-22}$ & $1 \times 10^{-22}$ \\
\hline${ }^{226} \mathrm{Ra}$ & $4 \times 10^{-4}$ & $4 \times 10^{-19}$ & $1 \times 10^{-20}$ & $3 \times 10^{-18}$ & $3 \times 10^{-20}$ & $6 \times 10^{-21}$ & $7 \times 10^{-21}$ \\
\hline${ }^{239} \mathrm{Pu}$ & $2.8 \times 10^{-5}$ & $2 \times 10^{-18}$ & $2 \times 10^{-19}$ & $4 \times 10^{-18}$ & $1 \times 10^{-19}$ & $1 \times 10^{-19}$ & $1 \times 10^{-19}$ \\
\hline
\end{tabular}

where, $\sum_{t=1}^{\infty} C_{d}$ is infinite, but $\Sigma C$ is finite and is calculated for every nuclide concerned as given in Table 1.

Table 1. Results of calculation of $C_{c}$ of different radionuclides in the North Pacific with different sets of diffusion coefficients (Unit: $\mathrm{Ci} / \mathrm{cm}^{3}$ ).

\section{Results and discussions}

1) In Table 1 and Fig. 2 are shown the results of calculations of the accumulated concentration of ${ }^{60} \mathrm{Co},{ }^{3} \mathrm{H},{ }^{90} \mathrm{Sr},{ }^{226} \mathrm{Ra}$ and ${ }^{239} \mathrm{Pu}$ at the above mentioned location ( $x=$ $y=0, z=4,000 \mathrm{~m})$ in the case of the successive annual release of $1 \mathrm{Ci}$. The calculations were carried out by using different values of the diffusion coefficients both in the vertical and the horizontal directions.

As shown in Table 1 and Fig. 1, there are the following relations between diffusion coefficients and concentrations.

a. The highest concentration is obtained for every nuclide, especially for ${ }^{60} \mathrm{Co},{ }^{3} \mathrm{H}$ and 


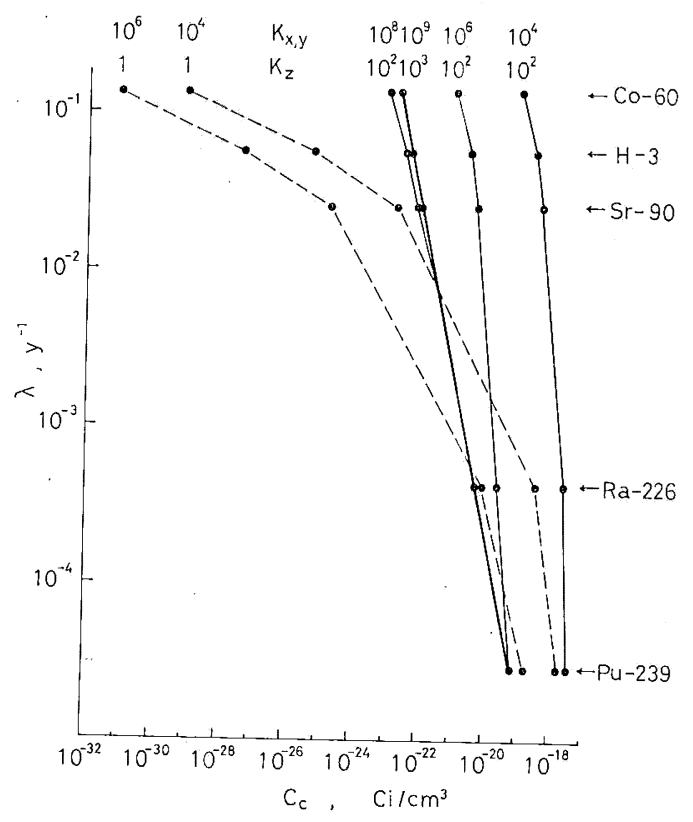

Fig. 2. $C_{c}$ of different radionuclides in the North Pacific with different sets of diffusion coefficients.

${ }^{90} \mathrm{Sr}$, when $K_{x}$ and $K_{y}$ are $10^{4} \mathrm{~cm}^{2} / \mathrm{s}$ and $K_{z}$ is $10^{2} \mathrm{~cm}^{2} / \mathrm{s}$.

b. The range of variation in concentration with different diffusion coefficients is larger for a nuclide with a larger decay constant.

c. As pointed out in the other report by MiYAKE and SARUHASHI (1976a), the relation between the concentration and the radioactive decay constant is important. In this connection, it is found that in the case of $K_{z}=1 \mathrm{~cm}^{2} / \mathrm{s}$, the concentration ratio is much different from the inverse ratios of decay constants for nuclides with a shorter half-life, while the concentration ratio is close to that of decay constants for longlived nuclides.

d. On the contrary, when $K_{z}$ is $10^{2}$ $\mathrm{cm}^{2} / \mathrm{s}$, the concentration ratio is nearly equal to the reciprocal of a decay constant, except for long-lived nuclides. However, for the larger value of $K_{x}$ and $K_{y}$ of $10^{8} \mathrm{~cm}^{2} / \mathrm{s}$, the concentration ratio of any nuclide becomes nearly equal to the inverse ratios of decay constants as is postulated from the law of radioactive disintegration.

2) In the next place, the relation between the diffusion coefficients and the change with time in the concentration is discussed. The first term of Eq. (3) expressing the concentration at the center of cloud decreases with time, while the summation of the second terms increases. Consequently, $C_{d}$ exhibits a maximum in the process of variation with time. After the occurrence of a maximum, the concentration $C_{d}$ decreases monotonously but should not diminish infinitely to zero. In a closed system it must approach the homogeneous mean concentration. In the case of the North Pacific it is $Q / W\left(\mathrm{~g} / \mathrm{cm}^{3}\right.$. or $\mathrm{mole} / \mathrm{cm}^{3}$ etc. $)$ where $W$ is the total volume of water in the North Pacific $\left(3.6 \times 10^{23} \mathrm{~cm}^{3}\right)$.

As $K_{x}, K_{y}$ and $K_{z}$ increase, the concentration at the center of cloud gradually lowers and approaches the homogeneous. concentration. When $K_{z}$ increases, not only the height of the maximal peak lowers, but also the time of occurrence of a peak is shortened. For example, when $K_{x}$ and $K_{y}$ are $10^{9} \mathrm{~cm}^{2} / \mathrm{s}$ and $K_{z}$ is $10^{3} \mathrm{~cm}^{2} / \mathrm{s}$, the homogeneous distribution of radionuclide attains in one year after a single release, while for $K_{x}$ and $K_{y}$ of $10^{8} \mathrm{~cm}^{2} / \mathrm{s}$ and $K_{z}$ of $10^{2} \mathrm{~cm}^{2} / \mathrm{s}$ it does in 20 years. In these cases, the accumulated concentration under the annual disposal of $1 \mathrm{Ci}$ is approximately expressed by the equation

$$
\Sigma C=\frac{1}{W \cdot \lambda} \mathrm{Ci} / \mathrm{cm}^{3}
$$

3) As discussed above in detail, since results of calculation of concentration depend largely on the diffusion coefficients, the value of the diffusion coefficients should be chosen carefully so as to obtain the proper and reasonable values which are valid in the real ocean.

With respect to the vertical diffusion coefficient, in the deep ocean, various values ranging from 0.1 to $10^{3} \mathrm{~cm}^{2} / \mathrm{s}$ have been proposed by various researchers up to the present.

In our laboratory, studies on the vertical and horizontal distributions of artificial 
radioactive substances such as ${ }^{137} \mathrm{Cs},{ }^{90} \mathrm{Sr}$, ${ }^{239+240} \mathrm{Pu}$ and ${ }^{3} \mathrm{H}$ in the wide area of the Pacific have been carried out extensively (Miyake et al., 1975; MryAKe and SugIMURA, 1976; SARUHASHI et al., 1975). From the results of these studies, the present authors have the conviction that the vertical turbulent diffusion coefficient in the deep layer of the Pacific is of the order of $10^{2}$ $\mathrm{cm}^{2} / \mathrm{s}$ (for example, Mryake and SarUHASHI, 1958).

Concerning the horizontal diffusion coefficient, it is well known that the order of diffusion coefficients depends on the size of turbulons and there is the following relation between the diffusion coefficient and the scale of diffusion phenomena (INOUE, 1950; HANZAWA, 1953):

$$
K=0.01 L^{4 / 3}
$$

When the above rule of $4 / 3$ power of scale is applied to the size of the North Pacific, the value of the turbulent diffusion coefficient on the horizontal direction should be of the order of $10^{9} \mathrm{~cm}^{2} / \mathrm{s}$ or more. In accordance with the above law, the horizontal diffusion coefficient of $10^{9} \mathrm{~cm}^{2} / \mathrm{s}$ was obtained in the North Pacific by MiYAKE and SARUHASHI $(1958,1960)$ on the basis of observation of distribution of radioactive substances originated from the Bikini-Eniwetok atolls in 1954. However, as this value is available only for the surface layer of the ocean, the probable value of the mean horizontal diffusion coefficient from the bottom to $1,000 \mathrm{~m}$ depth may be $10^{7}$ to $10^{8} \mathrm{~cm}^{2} / \mathrm{s}$. The latter values are $10^{5}$ or more times that of the vertical diffusion coefficients of $10^{2} \mathrm{~cm}^{2} / \mathrm{s}$ which agree well with the law of $4 / 3$ power. In this connection, it is noticed that NAN'NITI (1976, personal communication) and KAUFMAN et al. (1973) gave the same value as above to each diffusion coefficient. As described above, it is to be noted that, in the case when $K_{z}$ is $10^{2} \mathrm{~cm}^{2} / \mathrm{s}$ and $K_{x}$ and $K_{y}$ are $10^{8} \mathrm{~cm}^{2} / \mathrm{s}$, the results of calculation of concentration of each nuclide at the steady state are nearly equal to $1 / W \lambda \mathrm{Ci} / \mathrm{cm}^{3}$, are required from the law of radioactive disintegration as well as the size of the North
Pacific Ocean. This means that the calculated values of $\Sigma C$ or $C_{c}$ are very close to those of the infinite summation with respect to time $t$ of the product of the mean homogeneous concentration of nuclides at the steady state and exponential of $-\lambda t$.

\section{The definition of the high-level radioactive waste}

From the above results of calculation of concentration of each radioactive nuclide in the North Pacific, using the values of $10^{2}$ $\mathrm{cm}^{2} / \mathrm{s}$ and $10^{8} \mathrm{~cm}^{2} / \mathrm{s}$ of the diffusion coefficients respectively on the vertical and the horizontal direction, the definition of the high level radioactive waste and other matter not suitable for dumping at sea can be given.

In the first place, the maximum permissible concentration of each nuclide in the surface water is calculated by using the equation

$$
C_{a \max }=\frac{\mathrm{MPDI} \cdot x}{f \cdot \gamma}
$$

where MPDI is the maximum permissible daily intake of a certain radionuclide as recommended by the International Commission for Radiation Protection (ICRP) in $\mathrm{Ci}$ per day per person, $x$ is a safety factor $\left(3.3 \times 10^{-7}\right.$, MIYAKE and SARUHASHI, 1976), $f$ is an amount of daily intake of marine foods (100 $\mathrm{g}$ /day), and $\gamma$ is the concentration factor of a nuclide in marine foods $\left(80\right.$ for ${ }^{60} \mathrm{Co}, 1$ for ${ }^{3} \mathrm{H}, 0.2$ for ${ }^{90} \mathrm{Sr}$, 1 for ${ }^{226} \mathrm{Ra}$ and 10 for ${ }^{239} \mathrm{Pu}$ ).

By using the value of $C_{a \max }$, the limiting environmental capacity $(L, \mathrm{Ci} / \mathrm{y})$, or the maximum permissible annual rate of release is obtained when $C_{a}$ is assumed to be half of $C_{c}$. The results of calculation are given in Table 2.

Assuming that the upper limit of the amount of release of the solid radioactive wastes in the North Pacific is $10^{6}$ tons per year in total, each $L$ value is divided by $10^{6}$ $t / y$ which gives a criterion for the high-level radioactive waste and other matter. Therefore, the definition by the present authors 
Table 2. Maximum permissible annual rate of release in the North Pacific $(\mathrm{Ci} / \mathrm{y})$.

\begin{tabular}{c|c}
\hline Nuclide & $L \quad \mathrm{Ci} / \mathrm{y}$ \\
\hline${ }^{60} \mathrm{Co}$ & $8 \times 10^{6}$ \\
${ }^{3} \mathrm{H}$ & $2 \times 10^{10}$ \\
${ }^{90} \mathrm{Sr}$ & $2 \times 10^{6}$ \\
${ }^{137} \mathrm{Cs}$ & $2 \times 10^{6}$ \\
${ }^{226} \mathrm{Ra}$ & $2 \times 10^{2}$ \\
${ }^{239} \mathrm{Pu}$ & $6 \times 10^{2}$ \\
\hline
\end{tabular}

is that the high level radioactive waste and other matter is any waste or other matter with a concentration in $\mathrm{Ci}$ per ton exceeding

a. $10 \mathrm{Ci} / \mathrm{t}$ for $\beta / \gamma$ emitter (except tritium), $1 \mathrm{Ci} / \mathrm{t}$ for ${ }^{90} \mathrm{Sr}$ plus ${ }^{137} \mathrm{Cs}$.

b. $10^{4} \mathrm{Ci} / \mathrm{t}$ for tritium.

c. No long-lived emitter may be dumped.

The above values of criteria for the high-level radioactive waste are lower than those given by IAEA by a factor of 100 except for long-lived $\alpha$ emitters. According to the definition by IAEA, dumping of ${ }^{226} \mathrm{Ra}$ of $100 \mathrm{Ci} / \mathrm{y}$ and ${ }^{239} \mathrm{Pu}$ of $10 \mathrm{Ci} / \mathrm{t}$ at one site are allowable, but according to our view the dumping at sea of any long-lived $\alpha$ emitter must be as strictly prohibited as mercury and chlorinated hydrocarbon compounds.

\section{References}

Hanzawa, M., 1953: On the eddy diffusion of pumices ejected from Myojin-Reef in the Southern Sea of Japan. Records of Oceanograpic Works in Japan, 1, 18-22.

IAEA, 1975: Convention on the prevention of marine pollution by dumping of wastes and other matter. Information Circular INFCIRC/205/Add. 1, 10 Jan. 1975.

INOUE, E., 1950: The application of turbulence theory of oceanography. J. Met. Soc. Japan, $28,420$.

Kaufman, A., R.M. Trier and W.S. Broecker, 1973: Distribution of ${ }^{228} \mathrm{Ra}$ in the world ocean. J. Geophys. Res., 78, 8827-8848.

Mryake, Y. and K. SARuhashi, 1958: Distribution of man-made radioactivity in the North Pacific through summer 1955. J. Mar. Res., 17, 383-389.

- 1960: Vertical and horizontal mixing rates of radioactive material in the ocean. Disposal of radioactive wastes. 167-173.

, 1976a: Disposal of radioactive waste into deep seas. J. Radiat. Res., 17, 42-43.

- 1976b: A critical study on the IAEA definition of high level radioactive waste unsuitable for dumping at sea. Pap. Met. Geophys., 27, 75-80.

Miyake, Y., K. Saruhashi, Y. Katsuragi and T. KANAZAWA, 1962: Penetration of Sr-90 and Cs-137 in deep layer of the Pacific and vertical diffusion rate of deep water. J. Radiat. Res., 3, 141-147.

Miyake, Y., T. Shimada, Y. Sugimura, K. ShiGEHARA and K. SARUhashi, 1975: Distribution of tritium in the Pacific Ocean. Records of Oceanographic Works in Japan, 13, 17-32.

Mryake, Y. and Y. Sugimura, 1976: The plutonium content in the Pacific Ocean waters. In Transuranium Nuclides in the Environment, IAEA, Vienna, 91-105.

OECD-NEA, 1973: Radioactive waste disposal into the Atlantic. SEN/SAN (73), 10, 21st May 1973. Solid radioactive waste disposal into the sea. SEN/SAN (73), 30th May 1973.

Saruhashi, K., Y. Katsuragi, T. Kanazawa, Y. Sugimura and Y. MiYAKe, 1975: ${ }^{90} \mathrm{Sr}$ and ${ }^{137} \mathrm{Cs}$ in the Pacific waters. Records of oceanographic Works in Japan, 13, 1-15.

WebB, G. A. M. and F. Morley, 1973: A model for the evaluation of the deep ocean disposal of radioactive waste. NRPE-R 14, published by National Radiological Protection Board, UK. 


\section{北太平洋における放射性廃棄物処分の評価}

杉浦吉雄・猿橋勝子・三宅泰雄

放射性廃棄物の北太平洋に括ける深海処分に関する評仙を，拡散過程にもとづき，簡算化した閉鎖系モデルを用 いて行なった。

水平抢よび鉛值拡散係数の值をかえて計算した結果，执散係数が小さいと核種の相対濃度と放射壞変法則の間の くい違いが大きくなり，係数が大きくなれば，放出点直上に拈ける濃度は平均均一濃度にらかづき，放出量と壊変 量が等しい平衡時においては，海水中に打引る核種の存在量は壊変定数に反比例するといら放射壊変法則を満足す ることがしめされた。

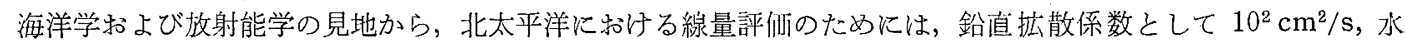
平拡散係数として $10^{8} \mathrm{~cm}^{2} / \mathrm{s}$ が適切かつ合理的であることが結論された。

高放射性廃棄物を次のよらに定義した。

1. $\beta / \gamma$ 放射体については $10 \mathrm{Ci} / \mathrm{t}$ ( ${ }^{3} \mathrm{H}$ を除く)。 ${ }^{90} \mathrm{Sr}+{ }^{137} \mathrm{Cs}$ については $1 \mathrm{Ci} / \mathrm{t}$.

2. ${ }^{3} \mathrm{H}$ については $10^{4} \mathrm{Ci} / \mathrm{t}$ 。

3. 長寿命 $\alpha$ 放射体は投棄できない。 